\title{
Pemberdayaan Melalui KUBE Bagi Peserta PKH di Kelurahan Sinar Baru Kabupaten Bangka
}

\section{Syarif}

Penggiat Kesejahteraan Sosial, Alumni UIN Sunan Kalijaga Yogyakarta, Indonesia

Sarif.iks@gmail.com

\begin{abstract}
This study aims to find out how to empower PKH participants through KUBE PKH Husna in Sinar Baru Village, Bangka Regency, Bangka Belitung Islands Province. The PKH is a conditional cash transfer to disadvantaged families with the aim of breaking the poverty chain. KPM PKH does not always get social assistance from the government. Therefore, during the transition period, especially PKH KPM which is still productive are included in the Joint Business Group (KUBE), which is known as KUBE PKH because the participants are from KPM PKH itself. KUBE PKH is intended as a social empowerment for beneficiary families to be independent and prosperous. This type of research is descriptive qualitative. The social empowerment is through the oyster mushroom cultivation business. The stages in the cultivation of oyster mushrooms there are three stages, namely planning, implementation and evaluation. The subjects in this study were KPM PKH. The results of this study indicate that there is an increase in income, knowledge and skills, the establishment of a sense of kinship and social intimacy among them, the establishment of a business branch of the cultivation of Oyster Mushroom KKH Husna, and an increase in the ability to market its business products.
\end{abstract}

Keywords: Social empowerment, KPM PKH, Kelompok Usaha Bersama.

\begin{abstract}
Abstrak
Penelitian ini bertujuan untuk mengetahui bagaimana pemberdayaan peserta PKH melalui KUBE PKH Husna di Kelurahan Sinar Baru Kabupaten Bangka Provinsi Kepulauan Bangka Belitung. Program keluarga harapan merupakan bantuan tunai bersyarat kepada keluarga yang kurang mampu dengan tujuan untuk memutuskan mata rantai kemiskinan. KPM PKH tidak selamanya mendapatkan bantuan sosial dari pemerintah. Oleh sebab itu, selama masa transisi khususnya KPM PKH yang masih produktif diikutsertakan dalam Kelompok Usaha Bersama (KUBE), yang dikenal dengan KUBE PKH sebab pesertanya dari KPM PKH itu sendiri. KUBE PKH dimaksudkan sebagai pemberdayaan sosial bagi keluarga penerima manfaat agar mandiri dan sejahtera. Jenis penelitian ini adalah deskriptif kualitatif. Pemberdayaan sosial tersebut melalui usaha budidaya Jamur Tiram. Tahapan-tahapan dalam budidaya jamur tiram terdapat tiga tahap yaitu perencanaan, pelaksanaan dan evaluasi. Adapun subjek dalam penelitian ini adalah KPM PKH. Hasil penelitian ini menunjukkan bahwa adanya peningkatan penghasilan, pengetahuan dan skill, terjalinnya rasa kekeluargaan dan keakraban sosial diantara mereka, terbentuknya cabang usaha budidaya Jamur Tiram KUBE PKH Husna, dan adanya peningkatan kemampuan dalam memasarkan produk usahanya.
\end{abstract}

Keywords: Pemberdayaan Sosial, KPM PKH, Kelompok Usaha Bersama.

Accepted: 22-03-2020; reviewed: 18-05-2020; published: 04-06-2020 Citation: Syarif, 'Pemberdayaan Melalui KUBE Bagi Peserta PKH di Kelurahan Sinar Baru Kabupaten Bangka', Mawa'izh: Jurnal Dakwah dan Pengembangan Sosial Kemanusiaan, vol. 11, no. 1

(2020), pp. 123-140. 


\section{A. Pendahuluan}

Fenomena kemiskinan tidak pernah habis-habisnya bahkan selalu menarik untuk diperbincangkan didunia politik, dan dunia kampus (seminar, forum diskusi, talk show) dengan tawaran gagasan dari berbagai kalangan para pakar praktisi maupun akademisi untuk memberikan solusi dalam pengurangan atau dan pengentasan kemiskinan. Tapi kenyataannya masih jauh yang diharapkan. Kemiskinan disebabkan berbagai faktor yaitu bencana sosial dan bencana alam, ketidakadilan sosial-ekonomi, kesempatan kerja minim, budaya konsumtif tinggi sedangkan kreatifitasnya lemah, malas, pesimis, pasrah pada nasib, dan sebagainya. Betapa menggelisahkan lagi, pada era yang sudah semakin canggih, kemiskinan tetap dominan. Bahkan kemajuan zaman yang diekspresikan melalui ilmu pengetahuan, teknologi, budaya dan modernitas, di satu sisi hanyalah memberikan kontribusi kesejahteraan pada sebagian kecil penduduk dunia. ${ }^{1}$ Sebagian besar orang Indonesia hidup dibawah garis kemiskinan. Orang miskin secara absolut mengalami kekurangan kebutuhan seperti sandang, pangan, papan, akses pendidikan, transportasi, dan layanan kesehatan. Kemiskinan dapat diartikan ketidakberdayaan atau ketidakmampuan atau kesulitan seseorang untuk memenuhi kebutuhan hidupnya sehari-hari.

Jika kita merujuk pada data BPS penduduk miskin pada Maret 2019 sebesar 9,41 persen, menurun 0,25 persen poin terhadap September 2018 dan menurun 0,41 persen poin terhadap Maret'2018. Jumlah penduduk miskin pada Maret 2019 sebesar 25,14 juta orang, menurun 0,53 juta orang terhadap September 2018 dan menurun 0,80 juta orang terhadap Maret 2018. Persentase penduduk miskin di daerah perkotaan pada September 2018 sebesar 6,89 persen, turun menjadi 6,69 persen pada Maret 2019. Sementara persentase penduduk miskin di daerah perdesaan pada September 2018 sebesar 13,10 persen, turun menjadi 12,85 persen pada Maret 2019. Dibanding September 2018, jumlah penduduk miskin Maret 2019 di daerah perkotaan turun sebanyak 136,5 ribu orang (dari 10,13 juta orang pada September 2018 menjadi 9,99 juta orang pada Maret 2019). Sementara itu, daerah perdesaan turun sebanyak 393,4 ribu orang (dari 15,54 juta

\footnotetext{
${ }^{1}$ Ambar, Teguh. Kemitraan dan Model- Model Pemberdayaan (Yogyakarta: Gava Media.2004), p. 3.
} 
orang pada September 2018 menjadi 15,15 juta orang pada Maret 2019). ${ }^{2}$ Salah satu daerah yang menjadi objek penelitian penulis adalah Bangka Belitung, daerah ini menunjukkan angka kemiskinan juga cukup tinggi, tepatnya Maret 2019, persentase penduduk miskin (penduduk dengan pengeluaran per kapita per bulan di bawah Garis Kemiskinan) mencapai 4,62 persen, turun sebesar 0,15 poin persen dibandingkan dengan kondisi September 2018 yang sebesar 4,77 persen. Persentase penduduk miskin di daerah perkotaan pada September 2018 sebesar 2,78 persen naik menjadi 2,85 persen pada Maret 2019. Sementara persentase penduduk miskin di daerah perdesaan pada September 2018 sebesar 7,16 persen mengalami penurunan menjadi 6,79 persen pada Maret 2019. Selama periode September 2018-Maret 2019, jumlah penduduk miskin di daerah perkotaan naik sebanyak 1,09 ribu orang (dari 22,22 ribu orang pada September 2018 menjadi 23,31 ribu orang pada Maret 2019), sementara di daerah perdesaan turun sebanyak 2,64 ribu orang (dari 47,71 ribu orang pada September 2018 menjadi 45,07 ribu orang pada Maret 2019). ${ }^{3}$

Meskipun data BPS di atas menunjukkan adanya penurunan angka kemiskinan, tetapi jumlah itu tidak sebanding dengan jumlah penduduk Indonesia. Banyaknya angka kemiskinan pastinya akan memiliki dampak yang akan terjadi kedepannya seperti kerawanan sosial, tindak kejahatan (pencurian, perampokkan, begal, modus penipuan, pembunuhan), pemicu terjadinya disintegrasi sosial, kesenjangan sosial, konflik berkepanjangan, kemerosotan mental, menjadi beban sosial masyarakat dan pemerintah, mempengaruhi pertumbuhan dan pembangunan ekonomi, dan sebagainya. Oleh sebab itu, pemerintah selalu berusaha dan berkewajiban untuk menuntas kemiskinan sesuai dengan amanat Pembukaan Undang-Undang Dasar Negara Republik Indonesia Tahun 1945 alinea ke empat bahwa negara mempunyai tanggung jawab untuk memajukan kesejahteraan umum dalam rangka mewujudkan tujuan bangsa Indonesia, bahkan Dalam Undang-Undang RI No. 25 Tahun 2009 tentang Layanan Publik dikatakan negara berkewajiban melayani setiap warga negara dan penduduk untuk memenuhi hak dan kebutuhan dasarnya. Demi pelaksanaan amanat tersebut, negara Indonesia berusaha

2 Badan Pusat Statistik, https://www.bps.go.id/pressrelease/2019/07/15/1629/persentasependuduk-miskin-maret-2019-sebesar-9-41-persen.html , di unduh pada tanggal 25/02/2020.

${ }^{3}$ Badan Pusat Statistik Provinsi Kepulauan Bangka Belitung, https://babel.bps.go.id/pressrelease/2019/07/15/661/maret-2019--persentase-penduduk-miskinbangka-belitung-4-62-persen.html , diunduh pada tanggal 25/02/2020. 
memberikan social service dan pengembangan kesejahteraan sosial secara terencana, terarah, dan berkelanjutan dengan sasaran atau diprioritaskan pada mereka yang memiliki kriteria masalah sosial kemiskinan.

Dalam rangka percepatan penanggulangan kemiskinan sekaligus pengembangan kebijakan di bidang perlindungan sosial, pemerintah melalui Kementerian Sosial di tahun 2007 hingga saat ini telah melaksanakan salah satu program yaitu Program Keluarga Harapan. Program keluarga harapan merupakan sebuah program bantuan tunai bersyarat kepada keluarga miskin, atau dalam istilah internasional dikenal dengan Conditional Cash Transfers (Kementerian Sosial RI. 2016). Tujuan dari program ini ialah untuk mengurangi angka dan memutuskan rantai kemiskinan, mengubah perilaku yang kurang mendukung peningkatan kesejahteraan dari kelompok paling miskin, dan meningkatkan kualitas sumber daya manusia.

Untuk menunjang efektivitas pengentasan kemiskinan, Kementerian Sosial bekerjasama dengan Badan Perencanaan Pembangunan Nasional (Bappenas) merancang program lanjutan bagi peserta $\mathrm{PKH}$ yang mengikuti masa transisi. Program lanjutan ini dilaksanakan dengan memberikan bantuan stimulan bagi rumah tangga atau keluarga secara berkelompok, yang dikenal dengan nama Kelompok Usaha Bersama (KUBE). Mengingat pesertanya berasal dari peserta $\mathrm{PKH}$, maka nama program ini lebih dikenal dengan nama KUBE PKH. KUBE memberikan bantuan bagi kelompok peserta program keluarga harapan untuk memiliki usaha produktif. KUBE PKH dimaksudkan sebagai pemberdayaan sosial bagi keluarga program keluarga harapan yang sedang dalam periode transisi agar memiliki kemandirian dan penghidupan yang berkesinambungan sekalipun lepas dari program keluarga harapan. ${ }^{4}$

\section{B. Kerangka Konsep}

\section{Pemberdayaan Sosial}

Pemberdayaan berasal dari kata daya yang berarti kekuatan. Pemberdayaan berarti upaya untuk memperoleh kekuatan. Konsep pemberdayaan di Indonesia ini mengadopsi dari bahasa Inggris yaitu dari kata empowerment. Konsep ini lahir dari

${ }^{4}$ Nainggolan, Togiaratua. Pusat Penelitian dan Pengembangan Kesejahteraan Sosial, Kementerian Sosial RI SOSIO KONSEPSIA Vol. 5, No. 03, Mei - Agustus, Tahun 2016. Jakarta Timur. 
perkembangan alam pikiran masyarakat dan kebudayaan Eropa yang muncul pada dekade 70-an yang berkembang terus hingga saat ini. Secara historis, empowerment pada masyarakat Eropa modern merupakan aksi emansipasi dan liberalisme dari totaliterisme keagamaan. Emansipasi dan liberalisme serta penataan terhadap segala kekuasaan dan penguasaan inilah yang kemudian menjadi substansi dari pemberdayaan. ${ }^{5}$

Merujuk pada disiplin ilmu-ilmu sosial, "pemberdayaan" menjadi salah satu fokus kajian teoritis dan praktik. Kata pemberdayaan berasal dari kata "daya' yang berarti kuat, mendapat awalan "ber" menjadi "berdaya" artinya mempunyai kekuatan atau kemampuan. ${ }^{6}$ Menurut Undang-Undang Kesejahteraan Sosial No. 11 Tahun 2009, pemberdayaan adalah memberdayakan seseorang, keluarga, kelompok dan masyarakat yang mengalami masalah kesejahteraan sosial agar mampu memenuhi kebutuhannya secara mandiri. Ada beberapa kelompok yang dapat dikategorikan sebagai kelompok lemah atau tidak berdaya meliputi; Pertama, kelompok lemah secara struktural, baik lemah secara kelas, gender, maupun etnis. Kedua, kelompok lemah khusus, seperti manula, anak-anak dan remaja, penyandang cacat, dan masyarakat terasing. Ketiga, kelompok lemah secara personal, yakni mereka yang mengalami masalah pribadi dan/atau keluarga. Dalam bukunya sarif dan Munawir7, pemberdayaan dalam kacamata sosial meliputi beberapa hal, seperti system, structure, strategy, staff, skill, leadership style, and share value. Atau pemberdayaan dapat dimaknai sebagai sebuah kegiatan untuk memperkuat keberdayaan seseorang, kelompok lemah dalam suatu masyarakat.

Konsep pemberdayaan yang ditawarkan oleh Gunawan Sumodininggrat dalam bukunya Siti Kurnia W dilihat dari tiga sisi; 1) pemberdayaan dengan menciptakan suasana atau iklim yang berkembang. 2) pemberdayaan untuk memperkuat potensi ekonomi atau daya yang dimiliki masyarakat. 3) pemberdayaan melalui pengembangan ekonomi rakyat, dengan cara melindungi dan mencegah terjadinya persaingan yang tidak seimbang, serta menciptakan kebersamaan dan

${ }^{5}$ Rr. Siti Kurnia Widiastuti, dkk., Pemberdayaan Masyarakat marginal, (Yogyakarta: Pustaka Pelajar, 2015), p. 12.

${ }^{6}$ Sarif dan Munawir, Pemberdayaan Lansia Dalam Al-Qur'an, Telaah Nilai (Yogyakarta: Semesta Ilmu, 2016), p. 139.

7 Ibid., 
kemitraaan antara yang sudah maju dengan yang belum. ${ }^{8}$ Menurut Prijono dan Pranarka lihat buku Siti Kurnia W, dkk, pemberdayaan mempunyai dua makna, yakni sebagai berikut; a) mengembangkan, memandirikan, menswadayakan dan memperkuat posisi tawar menawar masyarakat lapisan bawah terhadap kekuatankekuatan penekan di segala bidang dan sektor kehidupan, b) Melindungi, membela dan berpihak kepada yang lemah, untuk mencegah terjadinya persaingan yang tidak seimbang dan terjadinya eksploitasi terhadap yang lemah. ${ }^{9}$ Tujuan utama pemberdayaan adalah memperkuat kekuasaan masyarakat, khususnya kelompok lemah yang memiliki ketidakberdayaan, baik karena kondisi internal maupun eksternal. ${ }^{10}$

Tahapan strategi yang harus dilakukan dalam pemberdayaan masyarakat, yaitu sebagai berikut; pertama, membantu masyarakat dalam menemukan masalahnya. Kedua, melakukan analisis (kajian) terhadap permasalahan tersebut secara partisipatif. Kegiatan ini biasanya dilakukan dengan cara curah pendapat, membentuk kelompok-kelompok diskusi, dan mengadakan pertemuan warga secara periodic (terus-menerus). Ketiga, menentukan skala prioritas masalah, dalam arti memilah dan memilih setiap masalah yang paling mendesak untuk diselesaikan. Keempat, mencari penyelesaian masalah yang sedang dihadapi, antara lain dengan pendekatan sosio-kultural yang ada dalam masyarakat. Kelima, melaksanakan tindakan nyata untuk menyelesaikan masalah yang sedang dihadapi. Keenam, mengevaluasi seluruh rangkaian dan proses pemberdayaan itu untuk dinilai sejauh mana keberhasilan dan kegagalannya.

Tujuan pemberdayaan sosial melalui bantuan stimulan kelompok usaha bersama program keluarga harapan sebagai berikut (Kementerian Sosial: 2014c: 10); a), tewujudnya sinergitas program antara PKH dan pemberdayaan melalui KUBE dalam rangka meningkatkan kehidupan anggota KUBE untuk hidup secara layak. $b$ ), terwujudnya suatu kondisi yang dapat memberikan jaminan akan keberlangsungan

${ }^{8}$ Siti Kurni Wiadiastuti, dkk. Pemberdayaan Masyarakat Marginal, p. 12-13.

${ }^{9}$ Ibid...p. 13.

${ }^{10}$ Edi Suharto. Cet. Kelima. Membangun Masyarakat Memberdayakan Rakyat. Bandung: Refika Aditama.2014 ), p. 60. 
kehidupan sosial ekonomi anggota KUBE peserta PKH, c), terwujudnya kemandirian anggota KUBE dalam pengelolaan usaha ekonomis produktif. d), meningkatkan pendapatan anggota KUBE sebagai dampak dan pengembangan usaha ekonomis produktif. e), meningkatnya kondisi kehidupan dan kesejahteraan sosial anggota KUBE.

\section{Keluarga penerima manfaat Program Keluarga Harapan dan KUBE}

Program keluarga harapan merupakan sebuah program bantuan tunai bersyarat kepada keluarga miskin. Bantuan ini diberikan kepada keluarga miskin yang memiliki komponen yaitu komponen kesehatan (ibu hamil/nifas, anak usia di bawah 6 tahun), komponen pendidikan (SD, SMP, SMA), dan komponen kesejahteraan sosial (lansia usia 70 tahun ke atas, disabilitas berat). Banyaknya bantuan yang diberikan tergantung pada komponen yang dimiliki oleh keluarga. Bantuan tersebut berupa uang non tunai yang disalurkan melalui rekening kpm selama tiga bulan sekali. Bantuan itu diberikan tidak sama antara satu pengurus keluarga dengan pengurus keluarga yang lain artinya berdasarkan komponen yang dimiliki dalam keluarga. Program keluarga harapan adalah salah satu program yang cukup efektif untuk mengentaskan kemiskinan. Sebab, program ini tidak sebatas untuk memberikan bantuan uang nontunai saja akan tetapi penanaman mental anti miskin, pengetahuan tentang tiga komponen di atas melalui p2k2 (pertemuan peningkatan kemampuan keluarga). P2k2 disampaikan kepada keluarga penerima manfaat oleh pendamping PKH tidak hanya berupa pengetahuan pendidikan terhadap tiga komponen di atas melainkan juga memotivasi kpm agar mereka berkomitmen sebagai penerima bantuan sosial serta mempersiapkan mental agar mereka betul-betul siap jika sewaktu-waktu mereka harus di graduasi dari peserta program keluarga harapan. Sebab keluarga penerima manfaat program keluarga harapan tidak selamanya mendapatkan bantuan, jika sudah mampu maka mereka wajib di graduasi dari penerima bantuan sosial, bahkan ada diantara mereka tidak memiliki komponen-komponen seperti di atas tentunya wajib di graduasi. Sedangkan Kelompok Usaha Bersama (KUBE) merupakan kelompok keluarga miskin yang dibentuk, tumbuh, dan berkembang atas prakarsanya dalam melaksanakan Usaha Ekonomi Produktif (UEP) untuk 
meningkatkan pendapatan dan kesejahteraan sosial keluarga. ${ }^{11}$ Kelompok usaha bersama PKH merupakan strategi pemberdayaan secara kelompok oleh pemerintah untuk mengentaskan kemiskinan dalam bentuk modal usaha, yang dijalankan secara bersama-sama anggota PKH dengan didampingi oleh seorang pendamping sosial. Kelompok usaha bersama mempunyai fungsi sebagai wadah pertemuan untuk berbagi dan memecahkan masalah terutama masalah terkait kelompok usaha yang dijalankan, memberikan solusi terhadap masalah yang muncul, dan wadah kerjasama untuk mempermudah akses modal.

\section{A. Pemberdayaan Keluarga Penerima Manfaat PKH melalui KUBE}

Peserta keluarga penerima manfaat program keluarga harapan memiliki potensi untuk maju secara mandiri terutama yang produktif. Oleh sebab itu, dilakukanlah pemberdayaan kepada mereka melalui kelompok usaha bersama PKH Husna agar dapat mendorong mereka untuk mandiri secara totalitas tanpa ketergantungan dari pemerintah kedepannya khususnya bantuan PKH maupun bantuan sosial yang lainnya. Kelompok usaha bersama PKH Husna sebanyak sepuluh orang, yang terdiri dari ketua, sekretaris, bendahara dan anggota-anggotanya dengan didanai modal usaha sebesar 20 juta rupiah. Sebagai tindaklanjut pemberian bantuan stimulan, maka diperlukan seorang pendamping sosial. Pendamping KUBE PKH melalui seleksi, memenuhi persyaratan, dan mengikuti pemantapan (diklat). Pendamping sosial KUBE berperan terhadap KUBE PKH antara lain; melaksanakan tugas-tugas pendampingan, mengorganisasi pertemuanpertemuan dengan kpm KUBE, memberi penguatan kapasitas, dorongan (motivation) kepada anggota kelompok, membantu menyusun perencanaan dan pengelolaan usaha, membantu menyusun pertanggungjawaban dan pelaporan, serta membuat laporan pelaksanaan pendampingan secara berjenjang. Pendamping KUBE PKH Husna adalah seorang pendamping PKH itu sendiri. Keuntungan dari pendamping PKH yang menjadi pendamping KUBE adalah tidak canggung diantara para anggota dengan pendamping sosial KUBE dalam berkomunikasi/ berinteraksi, dan tentunya sudah saling memahami karakteristik satu dengan lainnya dikarenakan sudah terbiasa berinteraksi terutama dalam pertemuan P2K2 yang diadakan satu bulan sekali. Tujuan utama seorang

${ }^{11}$ Kementerian Sosial Republik Indonesia, https://kemsos.go.id/kube , diunduh pada tanggal 7 Maret 2020 
pendamping sosial KUBE yaitu untuk memperlancarkan implementasi usaha yang direncanakan dalam hal ini ialah pelaksanaan pemberdayaan KUBE PKH Husna. Proses Pelaksanaan dan pencapaian tujuan pemberdayaan terhadap keluarga penerima manfaat program keluarga harapan melalui KUBE, yaitu sebagai berikut:

\section{Penyelenggaraan Pemberdayaan KUBE Husna}

Kelompok usaha bersama program keluarga harapan merupakan strategi yang tepat untuk mengurangi kemiskinan bagi keluarga penerima manfaat PKH dalam periode transisi. Sesuai dengan pengertian dari Kementerian Sosial RI (2010:11) kelompok usaha bersama merupakan salah satu media untuk membangun kemampuan memecahkan masalah, memenuhi kebutuhan, melaksanakan peran sosial dengan mengembangkan potensi masyarakat khususnya keluarga miskin, yang mengintegrasikan aspek sosial dan ekonomi. Pemberdayaan kelompok usaha bersama PKH Husna memiliki goal selain menambah pendapatan juga meningkatkan wawasan dan skill. Dengan demikian, harapannya para keluarga penerima manfaat program keluarga harapan berinisiatif untuk membuka usaha sendiri dengan pengetahuan yang mereka dapatkan dari usaha tersebut. Dalam proses pemberdayaan usaha budidaya Jamur Tiram yang dilakukan oleh kelompok KUBE PKH, tentu memiliki beberapa tahap yang harus dilewati untuk mencapai hasil yang diharapkan. Tahapan-tahapan usaha budidaya Jamur Tiram yang dilakukan, yaitu sebagai berikut:

a. Tahap perencanaan

Perencanaan merupakan tahap awal program yang ada di kelompok usaha bersama PKH Husna. Sebelum merencanakan program usaha budidaya Jamur Tiram diawali dengan tahap penyadaran. Tahap ini salah satu tahap yang penting agar usaha yang direncanakan dapat berjalan dengan baik kedepannya. Seperti yang dijabarkan oleh Teguh Ambar ${ }^{12}$ bahwa tahap pertama dalam pemberdayaan adalah tahap penyadaran dan pembentukan perilaku sehingga merasa membutuhkan peningkatan kapasitas diri. Tahap penyadaran dalam program pemberdayaan ini dilakukan dengan pemberian motivasi. Tahap penyadaran dan pembentukan perilaku tidak begitu sulit bagi pendamping

\footnotetext{
12 Teguh Ambar. Kemitraan dan Model - Model Pemberdayaan. (Yogyakarta: Gava Media, 2014), p.83.
} 
KUBE PKH, sebab pendamping PKH atau pendamping KUBE PKH secara intens sudah melakukan hal tersebut minimal satu bulan sekali dalam pertemuan peningkatan kemampuan keluarga program keluarga harapan sebelum pembentukan KUBE PKH. Pertemuan ini bertujuan untuk memberikan education menyangkut tiga komponen yaitu pendidikan, kesehatan, dan kesejahteraan sosial. Disisi lain, juga disisipin dengan pembentukkan perilaku dan motivasi. Tetapi tidak menutup kemungkinan tahap penyadaran dan pembentukan perilaku usaha budidaya Jamur Tiram tetap dilaksanakan oleh pendamping KUBE PKH Husna sebelum mereka terjun langsung untuk mengimplementasikannya. Dengan alasan sifat keindividuan yang dimiliki masih tertanam dalam diri mereka serta penentuan usaha yang diinginkan. Sebagaimana yang disampaikan Indah ${ }^{13}$; sebelum terbentuknya KUBE PKH Husna sudah sering diberikan motivasi untuk mandiri dan siap untuk menerima keadaan jika sewaktu-waktu tidak menerima bantuan PKH, diberikan pengetahuan berupa pendidikan, pengasuhan anak, kesehatan gizi anak, perawatan lansia dapat diterapkan dirumah masing-masing, sedangkan untuk membuat suatu usaha bersama memang belum dan itu perlu dimotivasi biar satu pemikiran, karena tidak mudah untuk menyamai satu persepsi mereka yang memiliki latar belakang pendidikan yang beda-beda, seperti lulusan SD, SMP, dan SMA.

Tahap persiapan, sebelum merumuskan perencanaan usaha yang cocok buat keluarga penerima manfaat, pendamping terlebih dahulu tetap melakukan observasi dan memahami karakteristik anggota KUBE PKH agar memudahkan untuk mendapatkan informasi yang lebih dalam. Kemudian pendamping mengadakan pertemuan untuk wawancara kepada anggota kelompok untuk menggali potensi yang dimiliki terutama pengalaman-pengalaman mereka dalam dunia usaha. Banyak pilihan yang terdapat dalam benak mereka, ada yang menginginkan usaha toko sembako, usaha jual beli ikan, usaha kredit (peminjaman modal), budidaya jamur Tiram, usaha tanam tumbuh (sayur

13 Wawancara dengan ibu Indah selaku pendamping kube pkh Husna di kelurahan Sinar Baru Kabupaten Bangka pada tanggal 10 Januari 2019. 
mayur, cabe, kacang tanah), dan sebagainya. Beberapa anggota kelompok mengatakan, salah satunya ibu Ra; bahwa mereka memiliki pengalaman tentang cocok tanam jamur, bahkan orang dilingkungan mereka ada yang membuka usaha budidaya jamur tiram. Jamur yang ditanami tumbuh subur dan memanennya pun mudah. ${ }^{14}$ Sedangkan usaha yang lain seperti dipaparkan di atas sebagian besar mereka keberatan melakukannya, dengan pertimbanganpertimbangan tertentu. Hal ini menunjukkan, potensi terbesar yang dimiliki anggota kelompok adalah budidaya Jamur Tiram, selain mudah mengurusnya, dan mudah untuk menjualnya. Dengan alasan-alasan tersebut, pendamping sosial bersama anggota kelompok memutuskan usaha tersebut ditetapkan sebagai usaha bersama yang dijalankan. Dalam tahap perencanaan terdapat beberapa tahapan pemberdayaan keluarga penerima manfaat KUBE PKH Husna yaitu sebagai berikut; 1). Identifikasi kebutuhan, 2). Perumusan tujuan, 3). Penentuan sumber teknis, 4). Penentuan materi pemberdayaan KUBE, 5). Pengadaan sarana dan prasarana.

b. Tahap pelaksanaan

Berdasarkan identifikasi kebutuhan kegiatan yang dilaksanakan tidak hanya lingkup ekonomi saja, namun ditekankan kepada peningkatan pengetahuan dan keterampilan sebagai media pengembangan usaha yang dimiliki oleh keluarga penerima manfaat untuk kedepannya. Kegiatan pemberdayaan keluarga penerima manfaat ini setelah dilakukan observasi, wawancara, dan identifikasi kebutuhan maka ada beberapa tahapan dalam pelaksanaannya: 1). Tahap seleksi anggota KUBE PKH. Anggota KUBE PKH berasal dari keluarga penerima manfaat program keluarga harapan dengan syarat yang masih berusia produktif dan sudah menikah.

Dalam pelaksanaannya terdapat peserta yang keluar dari kelompok usaha tersebut maka dapat digantikan dengan kpm PKH yang lain terutama masih menerima bantuan PKH dan memenuhi syarat sebagaimana dijabarkan di atas. Teknis pelaksanaan kelompok usaha ini harus disepakati bersama seluruh

14 Wawancara dengan ibu RA selaku ketua kelompok kube pkh Husna di kelurahan Sinar Baru kabupaten Bangka pada tanggal 10 Januari 2019. 
anggota dan diketahui oleh pendamping. Salah satunya mengenai kontrak perjanjian; yaitu anggota yang rutin hadir dalam merawat usaha budidaya Jamur Tiram akan mendapatkan pembagian hasil yang lebih besar dari pada yang jarang hadir. Pembagian hasil ini merujuk pada absensi kehadiran kpm itu sendiri. Jika dibagi rata hasil penjualan, maka kpm yang sering hadir dalam merawat usaha Jamur Tiram, pastinya kecewa dengan kpm yang jarang pernah hadir. Peran pendamping sosial tetap mendorong anggota KUBE PKH Husna berjalan dengan baik dan solid, serta mendorong anggota untuk selalu aktif dalam membudidayakan usahanya. Sebagaimana yang disampaikan Indah ${ }^{15}$; Tugas pendamping mendorong mereka agar lebih giat, membantu menyusun laporan yang berjenjang, dan menampung semua aspirasi mereka serta memecahkan masalah yang mereka hadapi.

2). Penentuan jenis usaha. Jenis usaha yang dipilih oleh kelompok usaha bersama PKH Husna berdasarkan kesepakatan adalah "budidaya Jamur Tiram". Usaha ini didorong dengan alasan-alasan sebagaimana dipaparkan di atas. Selain itu yang menjadi alasan ialah usaha Jamur Tiram cukup menjanjikan, mudah dibudidayakan, tidak membutuhkan tempat yang luas, alat-alat yang digunakan tidak begitu banyak, dan tidak menyita waktu yang panjang sehingga peserta KUBE PKH dapat melakukan pekerjaan sehari-hari mereka seperti ngurus sawah, kebun lada, dan sebagainya.

3). Pelatihan keterampilan. Untuk menambah pengetahuan dan skill yang mendalam, para anggotanya dibekali pelatihan keterampilan, yaitu sebagai berikut; a). Pelatihan limbah plastik menjadi bunga, b). Pelatihan pemilihan bibit dan panen Jamur, c). Pelatihan perawatan media tanam, d). Pelatihan pengolahan Jamur, e). Budidaya Jamur, f). Pelatihan penguatan organisasi dan manajemen usaha.

Akan tetapi pelatihan keterampilan di atas tidak didapatkan peserta KUBE secara khusus dari nara sumber ahli (Ahli Pertanian Budidaya Jamur Tiram) yang seharusnya didatangkan oleh dinas sosial. Melainkan; para anggota belajar

15 Wawancara dengan Indah selaku pendamping kube pkh Husna di kelurahan Sinar Baru kabupaten Bangka pada tanggal 27 Desember 2018 
bersama dengan tetangga (non-PKH) yang memiliki usaha budidaya Jamur Tiram dengan di dampingi oleh pendamping sosial, belajar dari buku mengenai budidaya jamur tiram secara otodidak disertai praktek dari pengalamanpengalaman yang mereka miliki sebelumnya.

Keaktifan anggota KUBE PKH merupakan nilai pless atas kemandirian dan minat belajar yang kuat. Pembelajaran yang didapatkan dari pemilik usaha budidaya Jamur Tiram tersebut yaitu dengan cara peserta KUBE PKH mendengar dan mengamati secara langsung apa yang disampaikan pemilik dan kemudian mempraktikannya setelah mereka mendapatkan pembekalan tersebut. Artinya pelatihan yang diberikan ini sangat menarik bagi mereka tidak hanya mendengarkan secara teori dan mengamati saja melainkan langsung mempraktikan secara bersama-sama sehingga mereka mudah untuk mengerti, dan jika terdapat kesalahan dalam praktek tersebut langsung diberikan contoh yang benar. Hal ini merupakan metode yang cepat dipahami oleh peserta KUBE PKH Husna.

Dalam proses pertumbuhan dan perkembangan jamur Tiram hingga masa panen, jika anggota kelompok ini lupa apa yang mereka pelajari sebelumnya, mereka secara bersama-sama datang ke usaha budidaya jamur milik warga setempat untuk bertanya selain membuka buku budidaya Jamur Tiram belajar secara otodidak. Sebagaimana yang disampai ibu Ra; proses ke arah panen terkadang sedikit banyak lupa khususnya budidaya jamur yang dapat menghasilkan jamur berkualitas baik. Sebab kalau sekedar tanam semua orang pasti bisa, untuk mendapatkan kualitas ini yang penting. Sebab itu, ketika lupa mereka langsung nemui tetangga sebelah yang memiliki usaha sama seperti mereka. Tapi itu cukup sekali dua kali saja mereka bertanya, selepas itu mereka bisa melakukannya. ${ }^{16}$

Untuk penguatan organisasi dan manajemen usaha merupakan inisiatif dari Dinas Sosial sebagai nara sumber. Para nara sumber ini memberikan pemahaman tentang fungsi ketua, sekretaris, bendahara, dan anggota KUBE PKH 
Husna. Disisi lain, pihak Dinas Sosial juga melakukan monitoring 3 (tiga) bulan sekali untuk mengetahui kendala-kendala yang dihadapi, indikator pencapaian, dan memotivasi peserta KUBE PKH.

Berdasarkan observasi, tahapan-tahapan yang dilakukan para anggota dalam menjalankan usaha budidaya Jamur, diantaranya; 1) menyiapkan rumah jamur, yang digunakan sebagai tempat budidaya Jamur Tiram. Rumah jamur dikenal dengan istilah kumbung. Kumbung ini bagian atasnya terbuat dari daun rumpia buka dari seng atau asbes karena akan berpengaruh pada suhu yang panas mengakibatkan pertumbuhan jamur kurang baik, kerangka tiangnya dari bambu dan kayu, sedangkan tempat baglognya terbuat dari batang bambu yang dibelahbelah menjadi beberapa bagian dan ada juga sebagian dari kayu atau papan, sedangkan bagian lantainya memang sengaja tidak diplester supaya air yang digunakan untuk menyiram jamur dapat meresap dengan mudah ke dalam tanah. Kumbung yang sudah terbentuk rumah dibersihkan dengan menyemprotkan menggunakan pestisida. Setelah bau obat hilang maka dapat digunakan. Tujuannya agar pertumbuhan jamur tiram dapat subur, 2) menyiapkan baglog, baglog adalah media jamur yang terbuat dari serbuk kayu hasil pembuatan kursi, meja, lemari. Hal ini dikuatkan wawancara dengan ibu Ev; budidaya jamur tiram itu perlu baglod supaya jamur dapat tumbuh dengan baik. Untuk mendapatkan serbuk dengan cara meminta bahkan membeli serbuk dari tukang kusen hasil pembuatan lemar, kursi, meja, dan sebagainya. ${ }^{17}$ Budidaya Jamur Tiram merupakan jamur kayu sehingga baglog harus dibungkus dengan menggunakan plastik berwarna putih. Salah satu ujung plastik diberi lubang yang akan membuat jamur tumbuh keluar. 3) perawatan jamur, merawat jamur termasuk bagian penting dari budidaya jamur itu sendiri, yaitu sebagai berikut; (3.1). Media baglog, yang digunakan adalah serbuk kayu. (3.2). Steril Media, diantaranya steril dari hama atau bibit penyakit yang mungkin timbul kemudian hari, ruangan sekitaran jamur dan peralatan disteril dengan antiseptik, sirkulasi udara steril. (3.3). Nutri, nutri pada jamur tiram digunakan

17 Wawancara dengan ibu EV selaku ketua kelompok kube pkh Husna kelurahan Sinar Baru kabupaten Bangka pada tanggal 10 Januari 2019 
untuk perkembangan dan pertumbuhannya. Nutri yang tidak seimbang bahkan kurang akan berdampak kualitas pada jamur. Nutri itu dapat berupa kapur dan bekatul dimasukan ke media serbuk kayu yang sudah dibungkus dalam plastik. (3.4) pemanenan, sewaktu jamur sudah mekar dan telah membesar. Pembudidaya harus dengan segera mempanenkannya, jika proses panen terlambat satu minggu atau lebih. Maka akan berdampak pada warna jamur menjadi berubah kuning kecoklatan dan tudungnya menjadi pecah sehingga tidak layak dipasarkan lagi.

c. Tahap evaluasi

Tahap ini merupakan tahap akhir yang menentukan keberhasilan atau tidaknya program pemberdayaan peserta KUBE PKH Husna. Evaluasi program pemberdayaan ini dilakukan secara bersama-sama melalui diskusi dan tanya jawab, serta hasil pendapatan dari usaha budidaya Jamur Tiram. Evaluasi itu dapat dilakukan bulanan dan tahunan. Evaluasi bulanan dilakukan untuk melihat kendala-kendala yang dihadapi program dalam jangka waktu satu bulan, sedangkan evaluasi tahunan dilakukan untuk mengetahui pelaksanaan program pemberdayaan secara menyeluruh serta hasil pendapatan yang diperoleh. Disisi lain, menunjukkan bahwa kelompok usaha ini cukup terlibat aktif dalam setiap proses pembudidayaan Jamur Tiram hingga masa panen, meskipun ada beberapa orang orang jarang terlibat karena ada kegiatan yang tidak dapat ditinggalkan, dan sebagai buruh upah harian di kebun warga sekitar.

Berdasarkan hasil evaluasi secara menyeluruh, program pemberdayaan keluarga melalui KUBE PKH Husna cukup efektif dalam mencapai tujuan yang diharapkan.

\section{Hasil yang dicapai}

Dalam pemberdayaan keluarga penerima manfaat program keluarga harapan melalui KUBE PKH Husna, hasil yang dicapai yaitu; a). Peningkatan pendapatan dari pembagian hasil budidaya jamur, b). Peningkatan wawasan dan keterampilan baru yang menunjang kegiatan usaha dan pengembangannya, c). Meningkatkan kreativitas serta upaya aktif kelompok dalam memecahkan masalah dalam budidaya Jamur Tiram, d). Terjalinnya rasa kekeluargaan dan keakraban sosial antar anggota kelompok, e). Adanya 
inisiatif untuk membuka dan mengembangkan usaha budidaya Jamur Tiram secara mandiri dari setiap anggota kelompok yang hasilnya dapat menjadi pemasukan secara individu, f). Terbentuknya cabang usaha budidaya jamur Tiram KUBE PKH Husna yang dikelola oleh para anggota itu sendiri, g). Meningkatnya kemampuan dalam memasarkan produk Jamur Tiram serta pembukuan sederhana dari hasil penjualan.

\section{Faktor pendukung dan hambatan}

Dalam proses usaha budidaya jamur tiram tidak semudah membalik telapak tangan, ia membutuhkan ketekunan, keterampilan, pengetahuan, kekompakkan, keseriusan, ketelitian, dan lain sebagainya. Dalam pelaksanaan pemberdayaan KUBE PKH Husna memiliki beberapa faktor penghambat dan faktor pendukung. Faktor penghambat yang dihadapi dalam pemberdayaan ini, dapat dilihat dari dua sisi yaitu; pertama, anggotanya; a). Ketidakkonsistenan anggota KUBE PKH dalam menjalankan jadwal tugas yang sudah ditentukan secara bersama, b). Pola fikir masih bersifat individu, c). Keluar masuknya pengurus KUBE PKH dengan alasan kesibukan kerja kebun, sawah, dan lain sebagainya, d). Peserta PKH sekaligus anggota KUBE PKH yang tidak memiliki komponen lagi (non-eligble) memilih mengundurkan diri dari anggota, e). Kpm yang digraduasi karena mampu secara ekonomi, f). Kpm yang pindah alamat di luar kabupaten ataupun provinsi, g). Perencanaan program pemberdayaan ini tidak direncanakan secara matang, misalnya nara sumbernya ahli budidaya jamur Tiram tidak ditentukan oleh pihak stakeholder. kedua, Jamur Tiram; a). Daya simpan pasca panen tidak dapat bertahan lama yaitu maksimal dua hari, jika di freezer bisa mencapai satu minggu, lebih dari itu berdampak pada kualitas jamurnya yang makin memburuk dan tidak layak dimakan, b). Serangan hama. Kebersihan kumbung salah satu hal yang penting untuk dijaga dan dirawat, agar panen tidak gagal.

Disamping faktor penghambat, program pemberdayaan ini memiliki faktor pendukung yaitu, a). Keluarga penerima manfaat memiliki potensi sumber daya manusia tentang pengolahan budidaya Jamur Tiram, b). Kondisi cuaca dan alam mendukung, c). Minat belajar yang tinggi, d). Adanya pendamping sosial KUBE PKH, yang senantiasa mendampingi para anggotanya, dan memecahkan masalah yang dihadapi para anggotanya, serta membantu dalam laporan pertanggungjawaban, e). Dinas Sosial melakukan memonitoring atas perkembangan usaha, memberikan motivasi dan 
semangat dalam menjalankan usaha tersebut meskipun tidak secara rutin serta memecahkan kendala-kendala yang dihadapi anggota dan memberikan solusi.

\section{B. Penutup}

Peserta PKH adalah orang yang betul-betul berhak menerima bantuan sosial karena ketidakmampuan dalam memenuhi kebutuhan hidupnya. Bantuan itu diberikan tiga bulan sekali dengan syarat miskin dan memiliki tiga komponen sebagaimana dipaparkan di atas. Penerima bantuan PKH tidak selamanya mendapatkan bantuan sosial dari Kementerian Sosial, sehingga perlu untuk dipersiapkan secara mental bagi mereka agar bisa mandiri dan mampu meningkatkan kesejahteraan hidupnya. Pemberdayaan keluarga penerima manfaat PKH melalui KUBE PKH Husna merupakan salah satu upaya yang tepat untuk mengurangi angka kemiskinan serta mewujudkan kemandirian kpm PKH. Pemberdayaan itu berupa budidaya Jamur Tiram. Usaha ini dapat menambah wawasan atau dan pengetahuan bagi kpm dalam memahami masalah dan solusi memecahkan masalah yang ada pada budidaya jamur sehingga dapat menghasilkan secara kuantitas maupun kualitas yang baik. Dengan memiliki pengetahuan, skill, dan kreatifitas yang tinggi dalam pemberdayaan usaha budidaya Jamur Tiram sehingga mereka semua berinisiatif untuk melanjutkan dan membuka usaha secara mandiri maupun ilmu yang didapatkan dapat diajarkan kepada orang lain. 


\section{DAFTAR PUSTAKA}

Ambar, Teguh. (2004). Kemitraan dan Model - Model Pemberdayaan. (Yogyakarta: Gava Media.

Kementerian Sosial RI. 2016. Kebijakan Pelaksanaan Program Keluarga Harapan (PKH) "Direktorat Jendral Perlindungan dan Jaminan Sosial. Jakarta: Kementerian Sosial Republik Indonesia

Kementerian Sosial RI. (2010). Pedoman Kelompok Usaha Bersama. Jakarta: Kemensos

Nainggolan, Togiaratua, 2016. Pusat Penelitian dan Pengembangan Kesejahteraan Sosial, Kementerian Sosial RI SOSIO KONSEPSIA Vol. 5, No. 03, Mei - Agustus, Jakarta Timur

Sarif dan Munawir. 2016. Pemberdayaan Lansia Dalam Al-Qur'an, Telaah Nilai. Yogyakarta: Semesta Ilmu.

Suharto, Edi. 2014. Cet. Kelima. Membangun Masyarakat Memberdayakan Rakyat. Bandung: Refika Aditama.

Teguh Sulistiyani, Ambar. 2004. Kemitraan dan Model-Model Pemberdayaan. Yogyakarta: Gava Media.

Undang-Undang Kesejahteraan Sosial Nomor 11 Tahun 2009. Jakarta: Sinar Grafika.

Undang-Undang RI No. 25 Tahun 2009 tentang Layanan Publik

Widiastuti, Rr. Siti Kurnia, dkk. (2015) Cet. 1. Pemberdayaan Masyarakat marginal, Yogyakarta: Pustaka Pelajar.

Badan-Pusat-Statistik, https://www.bps.go.id/pressrelease/2019/07/15/1629/persentase-penduduk-miskinmaret-2019-sebesar-9-41-persen.html , di unduh pada tanggal 25/02/2020.

Badan Pusat Statistik Provinsi Kepulauan Bangka Belitung, https://babel.bps.go.id/pressrelease/2019/07/15/661/maret-2019--persentasependuduk-miskin-bangka-belitung-4-62-persen.html, diunduh pada tanggal 25/02/2020.

Kementerian Sosial Republik Indonesia, https://kemsos.go.id/KUBE , diunduh pada tanggal 7 Maret 2020. 